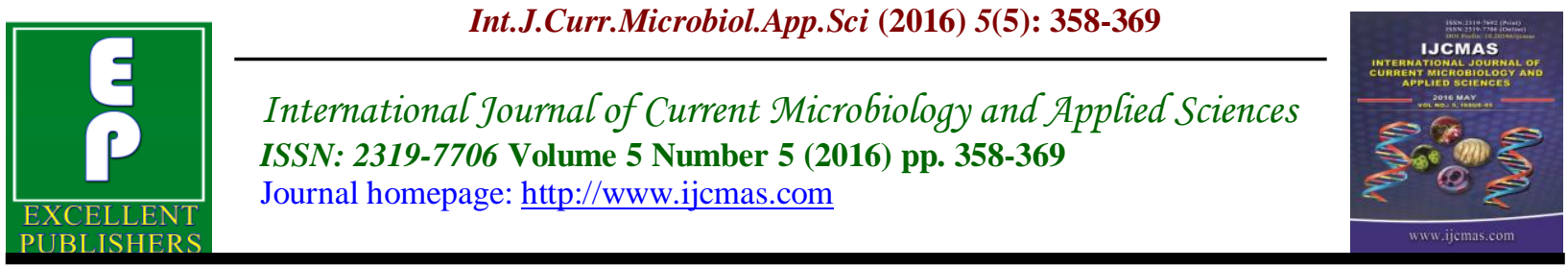

Original Research Article

http://dx.doi.org/10.20546/ijcmas.2016.505.037

\title{
Potential Pathogenic Bacteria of Wastewater Collectors from Abidjan (Côte d'Ivoire)
}

\author{
Coulibaly-Kalpy Julien ${ }^{1}$, Kouamé Y. Cyr-Kévin ${ }^{1,2}$, Ouattara Koffi Nouho², \\ Kouadio Kouamé ${ }^{3}$, Amon Lydie Nina ${ }^{1}$, Ehuié Pierre ${ }^{1}$, Yéo Kadjowely ${ }^{1}$, Bamba \\ Aboubacar ${ }^{1}$, Gourène Germain ${ }^{2}$ and M. Dosso-Bretin Mireille ${ }^{3}$
}
${ }^{1}$ Unité de chimie et de microbiologie environnementales, Département environnement et santé, Institut Pasteur de Côte-d'Ivoire, 01 BP 490 Abidjan 01, Côte d'Ivoire
${ }^{2}$ Laboratoire Pôle de Recherche Pêche et Aquaculture, UFR-SGE, Université NanguiAbrogoua, 02 BP 801 Abidjan 02, Côte d'Ivoire
${ }^{3}$ Unité d'éco épidémiologie, Département environnement et santé, Institut Pasteur de Côte d'Ivoire, 01 BP 490 Abidjan 01, Côte-d'Ivoire
*Corresponding author

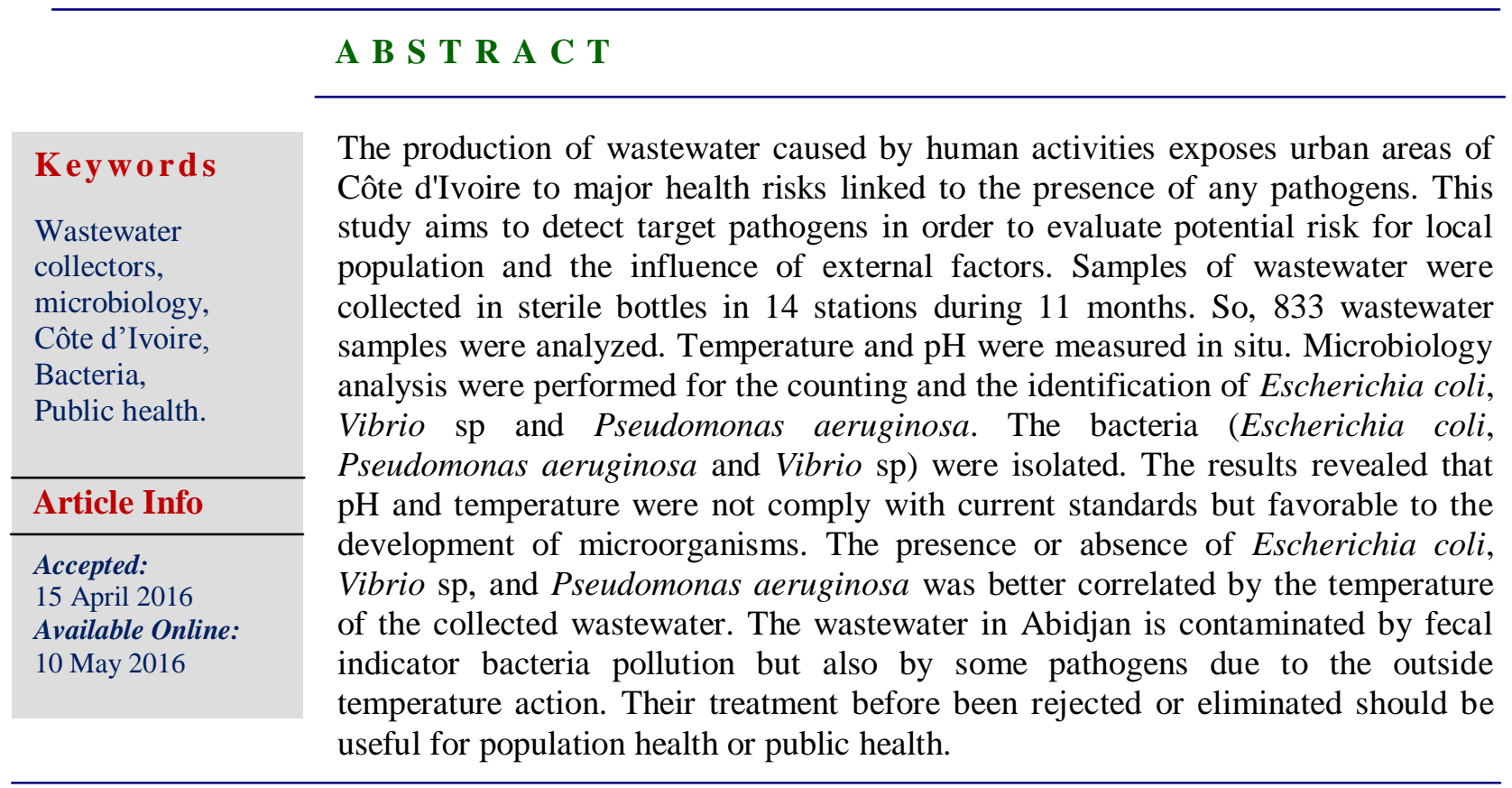

\section{Introduction}

Most urban areas in developing countries have major health risks facing the failure or lack of adequate sanitation, poor disposal of liquid waste, solid and insufficient drinking water (Collignon et al., 2000). Watercourses in urban areas or located within large cities, are particularly affected by physical, chemical and microbiological pollution (Grabow et al., 1996; Cabral et al., 2010). However, bacterial pollutants can have various microbiological sources (domestic sewage, industrial wastewater, etc...) (Dosso et al., 2012) and their presence in 
aquatic environments is a real public health problem for people using water resources (OMS, (1997); Koffi-Nevry et al., (2012)). The immediate consequences are the deterioration of living and this canincrease morbidity and mortality (Collignon et al., 2000). Indeed, waterborne diseases cause each year the deaths of several million people in the world and particularly in developing countries(Ouattara, 2000). There are 1.8 million people, $90 \%$ of children under five, mostly living in these countries that die each year from diarrheal diseases(OMS, 2004).

Moreover, the situation is accentuated in the slums of big African cities where population growth is between 3.4 and $9.4 \%$ (Collignon et al., 2000), causing an important wastewater production and huge sanitation problems. This wastewater may contained many pathogens (bacteria, viruses, protozoa, helminthes) responsible of many diseases (Cissé (1997); El Guamri et al., 2007)). If they are rejected without adequate treatment in the receiving environment, they will create many health problems including diarrhea, cholera and typhoid fever (OMS (1989); Dufour et al., 1994)).

The microorganisms are responsible of waterborne diseases mainly from the feces of humans and warm-blooded animals. These microorganisms are brought into surface waters, firstly, via discharges of raw sewage or treated, secondly, via runoff and leaching of agricultural soils contaminated by animal feces and spreading, on crops, manure or sewage sludge (sources) (Ouattara (2012)). Among the potentially pathogens bacteria transmitted by sewage, Enterococci Intestinal (EI) and Escherichia coli (E. coli), are considered as the indicators to evaluate the microbiological quality of surface water (Edberg et al., 2000; Fewtrell et al., 2001)). These indicators of fecal contamination are not pathogens but their presence indicates the existence of a contamination with feces and their abundance is indicative of the eventual presence of pathogenic microorganisms such as Vibrio sp. and Pseudomonas aeruginosa (Rose et al., 2004; Bennami et al., 2012)).

In West African sub-region, Abidjan is one of the few capitals with functional drainage systems for sewage and rainwater. However, only $30 \%$ of the Abidjan population is connected to the existing sewerage system and over $25 \%$ have no sanitation equipment (Métongo et al., 1993). In addition, among the existing sanitation facilities, the large open sky collectors, assigned exclusively to the storm waters which should be spilled into the lagoon Ebrié, is dysfunctional (Métongo et al., 1993). These collectors carry domestic sewage, storm water and effluent of various natures (Cissé et al., 2011). They receive wastewater from many municipalities: Abobo, Adjamé, Yopougon, Attécoubé, Marcory and Cocody. But this water is directly discharged without treatment into the lagoon Ebrié which is now in an advanced state of pollution (Scheren et al., 2004). They therefore constitute an environmental and health risk to aquatic organisms that live there and especially for local communities.

Indeed, the city of Abidjan knows since January 2011, a re-emergence of diarrheal diseases (including cholera) after 6 years of relative disappearance. Microbiological and epidemiological studies have confirmed cholera cases in Attécoubé, Adjamé, Cocody, Port-Bouet and Kumasi (Dosso et al., 2012). In addition, climate change, with warming temperatures could affect the persistence of some pathogens even some epidemics.

This study was established to evaluate the influence of physic-chemical parameters such as $\mathrm{pH}$ and temperature on the overall 
quality of wastewater, more particularly the microbiological quality. More specifically, (1) fecal contamination indicator bacteria $(E$. coli) and target pathogenic bacteria (.) will be detected, (2) physical and chemical parameters on the basis of $\mathrm{pH}$ and temperature will be determined, (3) and the relationship between $\mathrm{pH}$, temperature and the detection of bacteria will be established.

\section{Material and Methods}

Equipment of the biological material used for the realization of this study consists of waste water collected from different districts of Abidjan namely Cocody, Yopougon, Attecoubé, Abobo and Marcory. The programming language $\mathrm{R}$ and Multiple Correspondence Analysis enabled the statistical treatment of data.

\section{Sampling}

The wastewater samples were collected in the different municipalities, every three weeks (Figure 1). Samples were collected at the water surface in sterile bottles of $500 \mathrm{~mL}$ with a seal which was attached to a rope. Once collected, the samples were stored in a cooler with ice packs in order to maintain them at a temperature of about $4{ }^{\circ} \mathrm{C}$. Every withdrawals of operations were performed by the methods of Rodier (Rodier, 1996) and standards of AFNOR (Afnor, 1990). The samples were routed to the Chemistry Unit and environmental Microbiology laboratoryfor being analyzed according to the scheme defined by (Rodier, 1996; Servais et al., 2009a; Rodier et al., 2009) for isolation of Escherichia coli, Vibrio sp. and Pseudomonas aeruginosa.

\section{Physicochemical Parameters Analyses and Germs Isolation}

The physico-chemical parameters $(\mathrm{pH}$ and temperature) were measured in situ using a mixed $\mathrm{pH}$ electrode $323 / \mathrm{S}$ and $\mathrm{B}$, and analyzed by standard methods of the French Association for Standardization(AFNOR, 1990; AFNOR, 1986) and those of Rodier (Rodier, 1996).

The studied bacteria including E. coli, Pseudomonas aeruginosa and Vibrio sp were sought according to the methods of classical bacteriology. In $225 \mathrm{ml}$ of Buffered Peptone water was seeded $25 \mathrm{ml}$ wastewater sample to revive any $E$. coli and Pseudomonas present. Water Alkaline peptone was used for Vibrio sp research.

After 24 hours of incubation at $37^{\circ} \mathrm{C}$, Rapid'E.coli agar (REC2), Cetrimide agar and TBCS agar were seeded for the isolation of E. coli, and Vibrio sp. and Pseudomonas aeruginosa respectively. Biochemistry tests adapted of each bacteria genera were then used for species identification.

\section{Statistical Analysis}

Descriptive statistical techniques including strip charts were used for exploratory data analysis. In addition the analysis were deepened through factorial methods in particular, using the technique of Multiple Correspondence Analysis (MCA). This exploratory analysis was performed with $\mathrm{R}$. programming language

\section{Results and Discussion}

A total of 833 wastewater samples were collected as follows: Cocody $(\mathrm{n}=145)$, Yopougon $(\mathrm{n}=307)$, Attécoubé $(\mathrm{n}=176)$, Adjamé $(\mathrm{n}=52)$ Abobo $(\mathrm{n}=61)$ and Marcory $(\mathrm{n}=92)$.

The analyzed samples showed the presence of the main target bacteria (Escherichia coli, Vibrio sp. and Pseudomonas aeruginosa) in the collectors of different districts of Abidjan. Furthermore, there is a correlation between the detection of bacteria and the 
temperature of the collected wastewater.

\section{Descriptive Analysis}

Variation of the temperature and $\mathrm{pH}$ of wastewater sampling station

Figure 2 show the average values of the temperature and $\mathrm{pH}$ of wastewater sampling station.

The results show that the lowest average temperature per station for the waters studied are of the order of $25{ }^{\circ} \mathrm{C}\left(25{ }^{\circ} \mathrm{C}\right.$ (Lycée Technique station), $25,10{ }^{\circ} \mathrm{C}$ (Andokoi station) and $25,85{ }^{\circ} \mathrm{C}$ to the Corniche station). The highest average temperatures are close to $28{ }^{\circ} \mathrm{C}\left(28,03{ }^{\circ} \mathrm{C}\right.$ or (Cocody station), $28,05^{\circ} \mathrm{C}$ (Boribana station 2) $28,30{ }^{\circ} \mathrm{C}$ respectively in stations like Gouro market and Phoenix pharmacy, 28,36 ${ }^{\circ} \mathrm{C}$ (station CHU Yopougon) and $28,80{ }^{\circ} \mathrm{C}$ (Remblais station).

Lowest temperature $\left(20,40 \quad{ }^{\circ} \mathrm{C}\right)$ was recorded at the Lycée Technique station in July and the highest temperature $\left(34,40{ }^{\circ} \mathrm{C}\right)$ is from the Phoenix pharmacy station in May. The largest temperature variation was observed at the Phoenix pharmacy station (minimum and maximum temperatures of 22,20 and $34,40{ }^{\circ} \mathrm{C}$, respectively). The lowest temperature variation was observed at the Remblais station (minimum and maximum temperatures of 27,90 and 29,30 ${ }^{\circ} \mathrm{C}$, respectively).

The average $\mathrm{pH}$ range between 7,75 and 11,90. The lowest and highest $\mathrm{pH}$ were recorded respectively in the Boribana station $2(4,01)$ in the month of September and the station Gouro Market $(13,14)$ in August. The biggest change in $\mathrm{pH}$ was observed at the station Andokoi (minimum and maximum $\mathrm{pH}$ of 4,13 and 10,36 respectively). The lower $\mathrm{pH}$ change was observed at the Lycée
Technique station (minimum and maximum $\mathrm{pH}$ of 7, 15 and 9,68 respectively).

Detection of target bacteria in wastewater collection in the city of Abidjan

Samples of positive wastewater by bacteria are illustrated by Figure 3 .

For all samples analyzed in Cocody, the highest attendance percentages were observed for $P$. aeruginosa with minimum of $54,90 \%$ (Corniche station) and a maximum of $60 \%$ (Lycée Technique stations and Deux plateaux). The presence of $E$. coli percentages vary between $11,76 \%$ (station CHU Cocody) and 33,33\% (in Deux Plateaux station), those of Vibrio $s p$. vary between 10\% (Lycée Technique station) and 27,45\% (Corniche station). For samples analyzed in Yopougon, the highest attendance percentages were observed also for $P$. aeruginosa with a minimum of $17,65 \%$ (Phoenix pharmacy station) and a maximum of 38,10\% (CHU Yopougon). The presence of $E$. coli percentages vary between 17,65\% (Phoenix pharmacy station) and $34,52 \%$ (CHU Yopougon station) and those Vibrio sp. Range from 5,88\% (Phoenix pharmacy station) and 17,65\% (Gouro Station Market) in the municipality of Attécoubé, for $P$. aeruginosa detected with a minimum of $36,62 \%$ (Boribana station 2) and a maximum of $52,50 \%$ (Boribana station 1). For $E$. coli, the presence is between 15,38\% (mosque Boribana station) and 20\% (Boribana station 1). For Vibrio $s p$., presence is between 6,15\% (Mosque Boribana station) and 19,72\% (Boribana station 2).

Finally, in samples provided from Adjamé and Abobo municipalities, the highest attendance percentages were also observed for $P$. aeruginosa with $63,46 \%$, respectively (Fraternité Matin station) and 67,21\% 
(station Zoo) against 17,39\% at the station Marcory Remblais. The presence of E. coli in Fraternité Matin is estimated at 30,77\%, while the Zoo station level is $36,07 \%$ against $18,48 \%$ in Marcory Remblais. However, in the latter three stations, the percentage of presence forVibrio sp.is highest at Zoo station $(44,26 \%)$ while the lowest was recorded in Remblaisstation $(6,52 \%)$ against $15,38 \%$ in the station Fraternité-matin.

\section{Multidimensional Exploration}

The projection of quantitative variables in a Multiple Correspondence Analysis allows us to understand their positioning in relation to cloud variables (Figure 4).

The presence or absence of E. coli, Vibrio sp. and Pseudomonas aeruginosa is better correlated by the temperature of the collected wastewater.

In this study, we characterized the wastewater collectors Abidjan via the measurement of two physicochemical parameters (temperature and $\mathrm{pH}$ ) and microbiological parameters (E. coli, Vibrio sp. and $P$. aeruginosa).

The lowest average temperatures per station for the waters studied are in the order of $25^{\circ} \mathrm{C}$ at stations Lycée technique, Andokoi and Corniche. The highest average temperatures are close to $28^{\circ} \mathrm{C}$ at stations Cocody, Boribana 2, Gouro market, Phoenix Pharmacy, CHU Yopougon and embankments.

Overall, the average temperatures recorded for wastewater are near the threshold of 30 ${ }^{\circ} \mathrm{C}$

Generally indicated for the discharge of waste water (OMS, 1986; Bouzid et al., 2013). The wastewater from the city of
Abidjan are relatively warm with a maximum of $34,40{ }^{\circ} \mathrm{C}$ observed at the Phoenix pharmacy station during the main rainy season (GSP) in May. This same observation was made by Kadjabanga et al., (2006) which have conducted similar work with an observed temperature $\left(35^{\circ} \mathrm{C}\right)$ between the long dry season (GSS) in the months of March and the long rainy season (GSP) which usually begins in late May.

This value is lower than $35{ }^{\circ} \mathrm{C}$, considered indicative limit value for water for irrigation (Belghyti et al., 2009). This temperature rise can be explained by the influence of environmental conditions (rich in easily biodegradable organic matter, temperature, high light intensity, high humidity comparing to temperate regions, hydrological factors) (Houhamdi et al., 2006; Rochelle-Newall et al., 2015). However, the minimum temperature $(20,40$ ${ }^{\circ} \mathrm{C}$ (Lycée Technique station) recorded in the month of July at the GSP could be justified by the freshness due to the wind blowing monsoon in the months ofJuly and August. This wind promotes cooling water and gives them a lower temperature (Kouassi et al., 1990). The values of temperature are consistent with those of (Djèdjiho et al., 2013) who believe that the temperatures between $24{ }^{\circ} \mathrm{C}$ and $35{ }^{\circ} \mathrm{C}$ are favorable to the detection of bacteria.

The $\mathrm{pH}$ analysis of wastewater shows high variability in the Andokoi station (minimum and maximum $\mathrm{pH}$ of 4,13 and 10,36 respectively), reflecting the influence of various pollutions. This pollution from intensive human activities practiced by the local population, leaching of soil runoff and driving the waste of plant and animal origins, rich in organic nitrogen compounds which could affect the overall quality of wastewater (Close et al., 1989; Hassoune et al., 2006). However, the low variability 
observed at the Lycée technique station (minimum and maximum $\mathrm{pH}$ of 7,15 and 9,68 respectively) could be explained by a weak influence of pollution sources (domestic wastewater, industrial sewage and so on) (Close et al., 1989; Mbawala et al., 2010). But, the average $\mathrm{pH}$ values of wastewater sampling stations have higher average levels in the water discharge standard in the environment (OMS, 2006), ranging from 7,75 (CHU Yopougon) to 11,90 (Gouro market). The average $\mathrm{pH}$ noted for such water is basic to all stations unlike the results of (47) which recorded average $\mathrm{pH}$ acids for raw wastewater from the city of Cotonou, Benin.

Fig.1 Geographical location of the study area and the localities surveyed Abidjan district (Ahoussi et al., 2008)
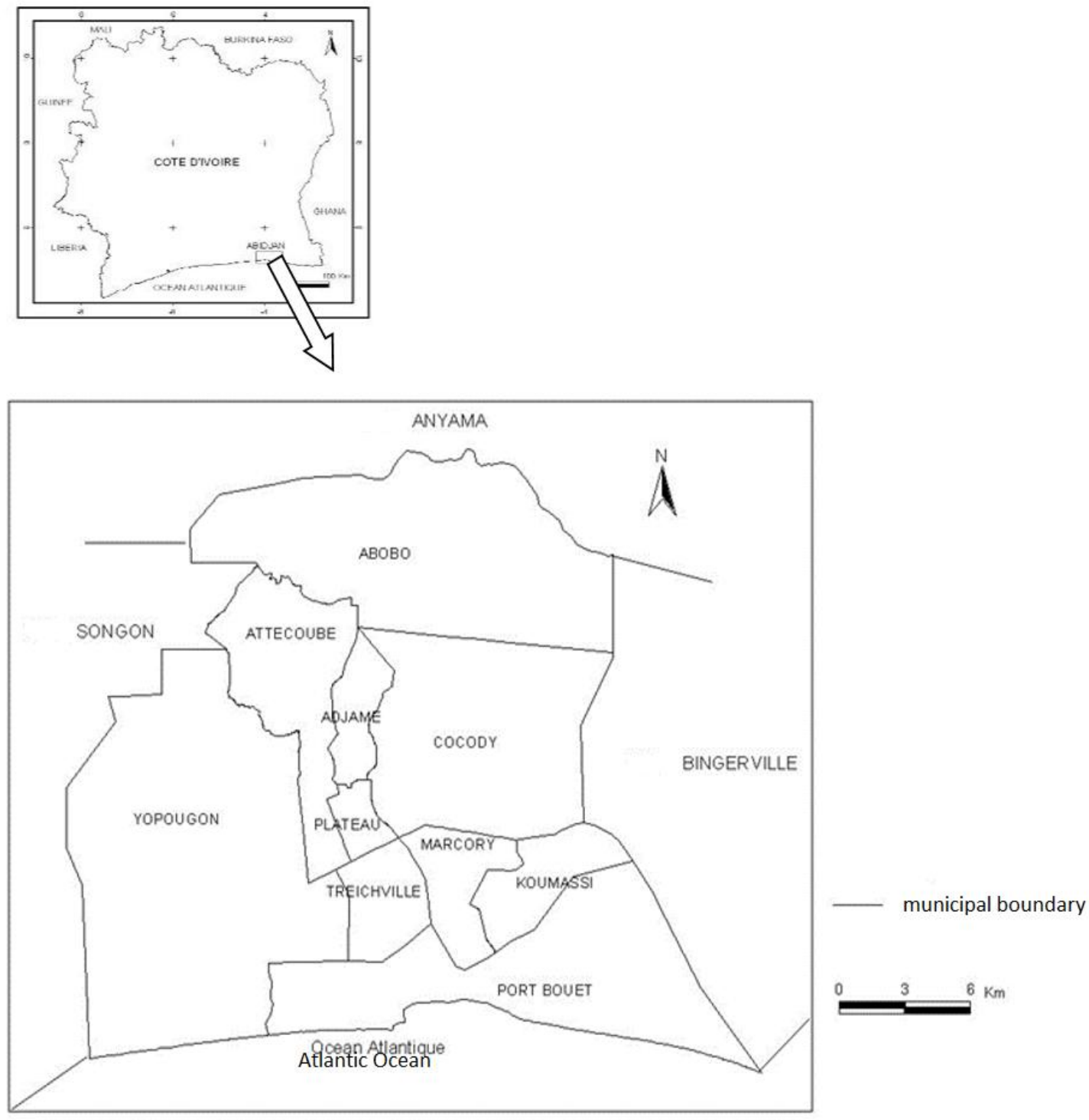
Fig.2 Physico-chemical parameters ( $\mathrm{pH}$ and temperature) recorded by station from January to November 2013.

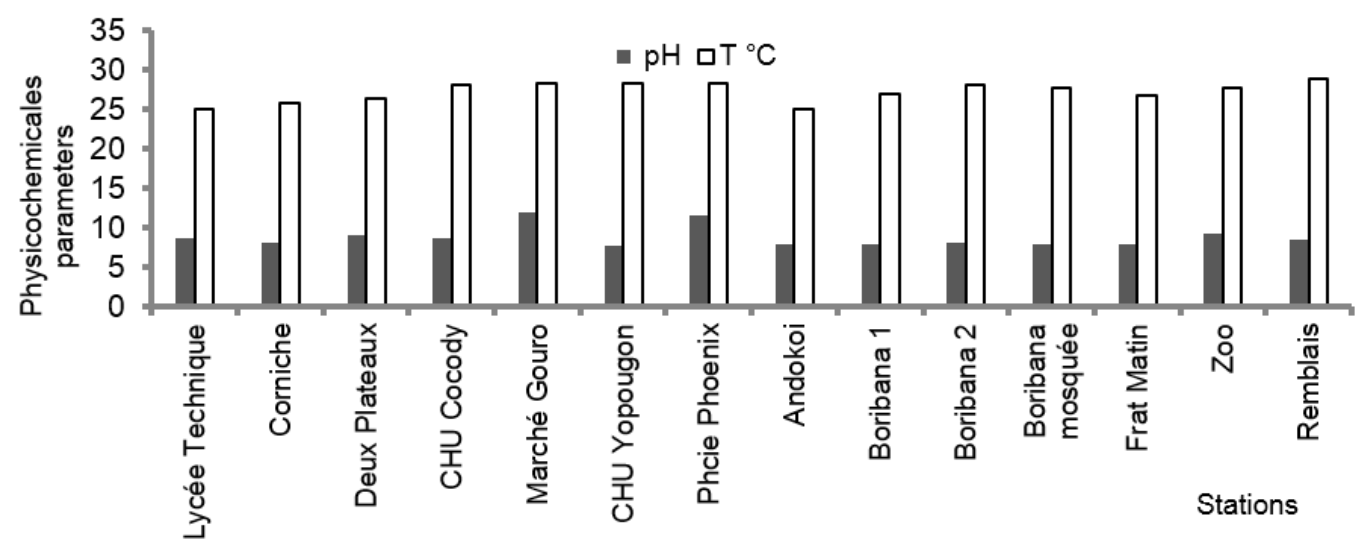

Fig.3 Presence of bacteria by sample in each sampling stations

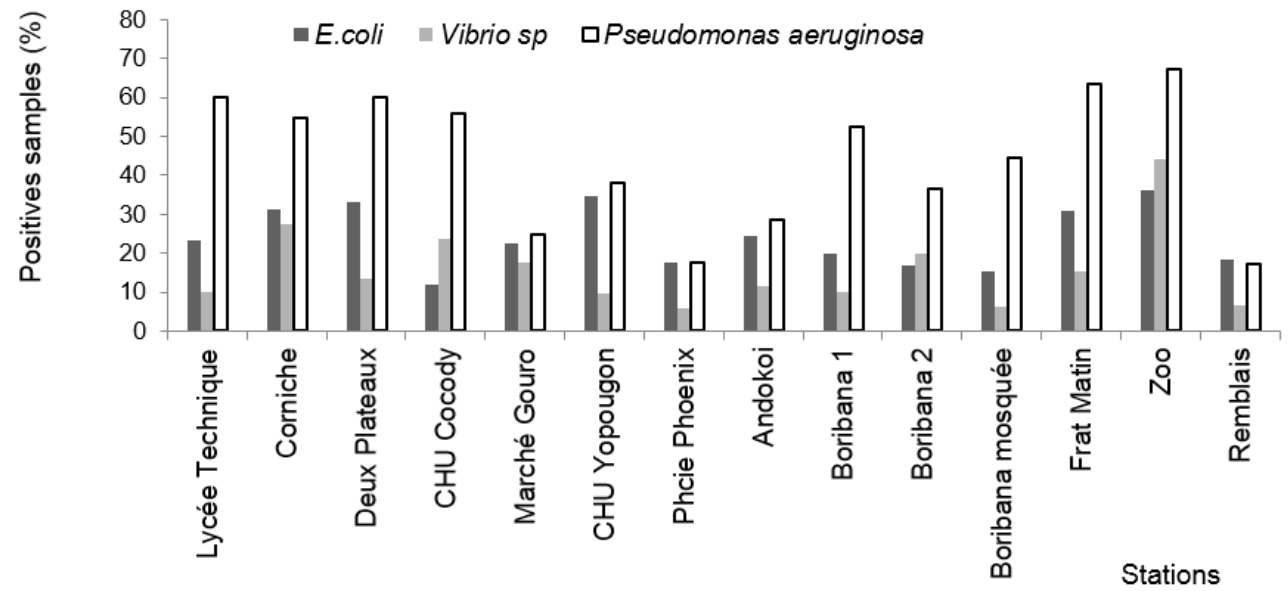

Fig.4 Cloud active variables with positioning of illustrative variables

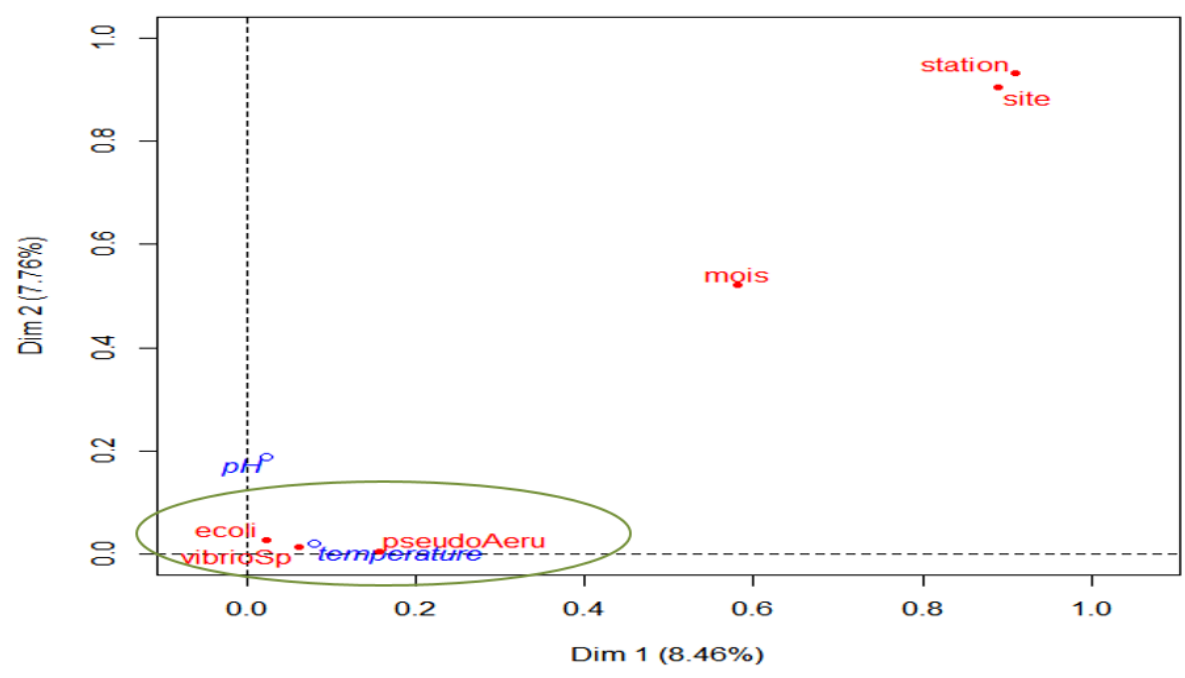


The results of our study are similar to those of (Abouelouafa, 2002) and (N'Diaye et al., 2011) which recorded $\mathrm{pH}$ slightly to moderately alkaline, respectively in wastewater cities of Oujda and the Kingdom of Morocco in Nouakchott Republic of Mauritania. This character of waste water in the city of Abidjan does not respond within the set standards of the World Health Organization, which recommended $\mathrm{pH}$ between 6 and 9 for water releases to the environment (OMS, 2006). This is the case, for example, at Phoenix pharmacy and Gouro market station in Yopougon where the average values of $\mathrm{pH}$, respectively of 11 , 90 and 11,64 are beyond the safety threshold.

In natural waters, the physic-chemical parameters such as acidity or alkalinity $\mathrm{pH}$ and temperature should not exceed a safe level, since they can cause a change in the characteristics of these waters leading to that cause a serious public health threat (Houhamdi et al., 2006).

Microbiological analysis focused on the detection of target pathogenic bacteria (Escherichia coli, Vibrio sp. and Pseudomonas aeruginosa).

The presence of E. coli, specific fecal pollution indicator (Adjahouinou et al., 2013; Edberg et al., 2000) in the analyzed water, clearly indicates contamination by fecal micro-organisms and therefore the epidemiological potential risk is to leave untreated discharge (Adjahouinou et al., 2013; Servais et al., 2006). Indeed, the presence of enteric bacteria should suspect many other pathogens (Adjahouinou et al., 2013; Elmund et al., 1999; Ajit et al., 2009). It is the same for Vibrio sp. and $P$. aeruginosa. It should however be noted that the positive rates recorded for $E$. coli are lower than those of raw water to the city of Oujda the Kingdom of Morocco
(Adjahouinou et al., 2013; Abouelouafa et al., 2002) and the registered rate for wastewater in Nouakchott Republic of Mauritania (Adjahouinou et al., 2013; N'diaye et al., 2011) and Ouargla (Adjahouinou et al., 2013; Hamdi et al., 2012). This phenomenon is due to the specificities linked either to the physicochemical parameters of these waters, or their origin (domestic or industrial).

P. aeruginosa shows a high positivity rate on all the 14 stations. This species in waters may constitute a health risk as highlighted by the work of Manizan et al., (Palleroni et al., 2002; Manizan et al., 2009) .The stations located in the municipality of Attécoubé receive wastewater from Adjamé municipality, crossing some homes and sites before emptying into the lagoon Ebrié. Previous studies have shown that following Adjamé, the municipality of Attécoubé, due to its proximity to Adjamé was hit by a cholera epidemic, especially in Boribana.

This case was confirmed by the Pasteur Institute of Côte d'Ivoire. Eventually the epidemic spread in 2011 to other neighboring municipalities (Yopougon, Abobo, Cocody and Marcory) (Koutouan (2012). These studies are consistent with the results from our research that signal the presence of Vibrio $s p$. in wastewater samples analyzed. The presence of bacteria in wastewater samples could be justified by the discharge of waste water into the gutters. Their presence is also justified by a number of inherent factors in agricultural activities around the stations, a development failure of these stations, proximity to pollution sources such as household waste, latrines and noncompliance basic hygiene by the population (Mbawala et al., 2010). Our study provides above all the existence of a correlation between the detection of bacteria (E. coli, Pseudomonas aeruginosa and Vibrio sp.) and the waste water temperature. 
In conclusion, this work enabled to detect Escherichia coli germs Vibrio sp. and Pseudomonas aeruginosa in wastewater collection in the city of Abidjan in 2013. The presence of these pathogens is related to the temperature rise in the waters and reveals the danger to local residents dumping sites for domestic wastewater. This untreated wastewater transit in urban areas via collectors often open and spilled into the lagoon Ebrié. Also, this study reveals the lack or absence of monitoring of wastewater discharges at the Abidjan sanitation, which highlights the need for better wastewater management to protect local residents but also the lagoon Ebrié.

Considering the results of this study which shows the need to set up a short-term wastewater drainage system via cutlery collectors and effectively maintain it in connected neighborhoods.

This will prevent the presence of sewage in the streets. In the long term, it is necessary to resize the sanitation system in the new development taking into account the potential occupancy rates. The waste water will be routed to wastewater treatment plants to prevent the pollution of receiving waters. The main outlets being at the lagoon Ebrié microbial pollution is a real environmental problem.

\section{Acknowledgment}

We would like to thank the Ministry of Environment, the heads of Pasteur Institut of Côte d'Ivoire and Nangui Abrogoua University. Also thank to personnal working in and near the collector.

\section{References}

Abouelouafa, M., H.El. Halouani, M. Kharboua, Berrichi, A. 2002.
Caractérisation physico-chimique et bactériologique des eaux usées brutes de la ville d'Oujda: canal principal et Oued Bounaïm. Actes de l'Institut Agronomique et Vétérinaire Hassan II (Maroc). 22(3) : 143-150.

Adjahouinou, D.C., B. Yehouenou, M.N.D. Liady and Fiogbé, E.D. 2013. Caractérisation bactériologique des eaux résiduaires brutes de la ville de otonou (Bénin). J. Appl. Biosci., 78: 6705-6713.

AFNOR, 1990. Recueil de normes françaises. Eaux: méthodes d'essais. $736 \mathrm{p}$.

Ahoussi, K.E., N. Soro, G. Soro, T. Lasm, M.S. Oga and Zadé, S. 2008. Groundwater Pollution in Africans Biggest Towns: Case of the Town of Abidjan (Côte d'Ivoire). European J. Scientific Res., 20(2): 302-316.

Ajit, K.P., C.A. Bhaskar and Anil, M. 2009. Occurrence and distribution of bacterial pathogens in coastal Indicators and waters of Orissa. Indian J. Marine Sci., 38(4): 474-480.

Bennami, M., H. Amarouch, A. Boukanjer, H. Nadre, M. Lalaoui, M. Allali and Cohen N. 2012. Influence des Facteurs Environnementaux Sur les Charges des Bactéries Fécales Dans le Littoral Méditerranéen du Maroc. European J. Scientific Res., 1(71): 2435.

Cissé, M., F. N’Guessan, Y. Karamoko, K. Tigoli, B.D.F. Djè, and Gourène, G. 2011. Charge parasitaire des eaux usées du collecteur « Gouro » traversant les communes d'Abobo, Adjamé et Cocody (District d'Abidjan, Côte d'Ivoire). Les technologies de laboratoire. 25(6): 96-105.

Cissé, G., 1997. Impact sanitaire de l'utilisation d'eaux polluées en agriculture urbaine - Cas de la 
maraîchère à Ouagadougou (Burkina Faso). Thèse de doctorat, Ecole Polytechnique Fédérale de Lausanne, Suisse. 267 p.

Close, M.E., L.R. Hodgson and Todgré, G. 1989. Field evaluation of fluorescent whitening agents and sodium tripolyphosphate as indicator of septic tank contamination in domestic wells. New Zealand J. Marine and Freshwater Res., 23: 563-568.

Collignon, B., Vezina, M. 2000. Les opérateurs indépendants des services de l'approvisionnement en eau potable et de l'assainissement en milieu urbain africain. Programme pour l'Eau et de l'Assainissement,92 p. http://www.wsp.org, Version (03/ 2010)

Dèdjiho, C.A., D. Mama, L. Tometin, I. Nougbodé, W. Chouti, D.C.K. Sohounhloué and Boukari, M. 2013. Évaluation de la qualité physicochimique de certains tributaires d'eaux usées du lac Ahémé au Bénin. J. Appl. Biosci., 70: 5608-5616.

DEEC, 2001. Eaux usées : Normes de rejets. Norme sénégalaise NS 05-061. Pp 27.

Dosso, M., A. Kacou-N'douba, K. J.Coulibaly, R. Ncho, C. Sissoko, S. Koffi, P. Ehui, S. Ncho, D. Saraka and Anné, J.C. 2012. Rapport Mission Cholera IPCI ACF. Institut Pasteur de Côte d'Ivoire : Département de Bactériologie Virologie-Unité de Bactériologie Clinique Cnr Cholera; Département Environnement et SantéUnité de Microbiologie Environnementale. $14 \mathrm{p}$.

Dosso, M., M. Coulibaly and Kadio, A. 1998. Place des diarrhées bactériennes dans les pays en développement.Manuscrit $\quad \mathrm{n}^{\circ} \mathrm{PF} 02$. Journée en hommage au Professeur A. DODIN. Accepté le 7 Décembre 1998. p 4.
Dufour, P., A.M. Kouassi and Lanusse, A. 1994.Les pollutions. In : Durand J-R., Dufour P., Guiral D., Zabi S.G. (Eds.) : Environnement et ressources aquatiques de Côte d'Ivoire, tome IILes milieux lagunaires. Edition ORSTOM. ISBN: 2-7099-1136-1, 320-331.

Edberg, S.C., E.W. Rice, R.J. Karlin and Allen, M.J. 2000. Escherichia coli: the best biological drinking water indicator for public health protection. J. Appl. Microbiol., 88: 106S-116S.

El Guamri, Y., Belghyti, D. 2007. Contamination des eaux usées du réseau d'assainissement liquide par les oeufs d'helminthes (cas de la ville de Kénitra, Maroc). Revue Microbiologique Industrielle Sanitaire et Environnementale. 1, 44-59.

El Haissoufi, H., S. Berrada, M. Merzouki, M. Aabouch, L. Bennani, M. Benlemlih, M. Idir, A. Zanibou, Y. Bennis and El Ouali, L. A. 2011. Pollution des eaux de puits de certains quartiers de la ville de Fès, Maroc. Revue de Microbiologie Industrielle Sanitaire et Environnementale, 1(5): 37-68.

Elmund, G.K., M.J. Allen and Rice, E.W. 1999. Comparison of Escherichia coli, total coliform and fecal coliform populations as indicators of wastewater treatment efficiency. Water Environ. Res., 71: 332-339.

Fewtrell, L., Bartram, J. 2001. Water quality: guidelines, standards and health. World Health Organization Water Series, pp 20-21.

Grabow, W.O.K. 1996. Waterborne Diseases: Update on Water Quality Assessment and Control. Water in Southern Africa, 22: 193-202.

Hamdi, W., M. Youcefi, Y. Touil, R. Bougrinat, N. Ferhi and Ould, E.H.M.D. 2012. Contribution à l'étude 
de quelques caractéristiques physico chimiques et hygiéniques des eaux usées issues de rejets de certaines localités de la cuvette de Ouargla (Sahara septentrional Est algérien): impact sur le milieu récepteur. Algerian J. Arid Environ., 2(1): 5663.

Houhamdi, M., C. Mebarki and Abbaci, S. 2006. Qualité microbiologique et physico-chimique des eaux des puits et des sources de la région d'Oum-ElBouaghi. Journal algérien sur les régions arides, 105-108.

Kadjangaba, E., Y. Travi and Puig, J-M. 2006. Influence des rejets d'eaux usées et des décharges sauvages sur la qualité des eaux souterraines de la ville de N'Djaména (TCHAD). $J$. algérien sur les régions arides, 101104.

Koffi-Nevry R., C.B.J. Assi, M. Koussemon, A.S. Wognin and Coulibaly N. 2011. Potential Enterobacteria risk factors associated with contamination of lettuce (Lactuca sativa) grown in the peri urban area of Abidjan Côte d'Ivoire). Int. J. Biol. Chem. Sci., 5(1): 279-290.

Kouassi, A.M., D. Guiral and Dosso, M. 1990. Variations saisonnières de la contamination microbienne de la zone urbaine d'une lagune tropicale estuarienne : Cas de la ville d'Abidjan (Côte d'Ivoire). Revue d'Hydrobiologie Tropicale, 23(3): 181-194.

Koutouan, G.G.M. 2012. Rapport de l'enquête sur la vulnérabilité au choléra des ménages et quartiers précaires d'Abidjan. 120p.

Lamrani, H., A. Chahlaoui, J. El Addouli and Ennabili, A. 2011. Evaluation de La qualité physico-chimique et bactériologique de l'Oued Boufekrane au voisinage des effluents de la ville de Meknès (Maroc). La science en liberté, 11111(3): 15p.

Manizan, N.P., T. Dadié, S. Koudou and Dosso, M. 2009. Risque sanitaire à Pseudomonas lié à la consommation des eaux embouteillées à Abidjan.Journal des Sciences Pharmaceutiques et Biologiques, 2(10): 65-70.

Mbawala, A., Abdou and Ngassoum, MB.2010. Evaluation de la pollution physico-chimique et microbienne des eaux de puits de Dang-Ngaoundéré (Cameroun), Int. J. Biol. Chem. Sci., 4(6): 1962-1975.

Métongo, B.S., N. Kaba and Kouassi A.M. 1993. Evaluation quantitative et qualitative des effluents et des polluants, OMS, Bureau Régional de l'Afrique (OMS \ AFRO) et CRO. $100 \mathrm{p}$.

N'Diaye, A.D., M. Kankou, B. Lo and Namr, K.I. 2011. Caractérisation de la pollution bactériologique des effluents de la ville de Nouakchott, irrigués dans le périmètre maraîcher de Sebkha. Int. J. Biol. Chem. Sci., 5(2): 748-754.

OMS, 1986. Directives de Qualité pour l'Eau de Boisson. Critères d'Hygiène et Documentation à l'Appui, $2\left(1^{\text {re }}\right.$ édn). OMS : Genève. 341 p.

OMS, 2004. Directives de qualité pour l'eau de boisson, $1 \quad\left(3^{\mathrm{e}} \quad\right.$ édn $)$. WSH_Guidelines_DrinkingWater_Qu ality-fr.doc. $110 \mathrm{p}$.

OMS, 2006. Guidelines for the safe use of wastewater, excreta and greywater. World Health Organization, Geneva. $36 \mathrm{p}$.

OMS, 2008. Guidelines for Drinking-water Quality, Incorporating 1 st and 2nd Addenda, Recommendations, $1 \quad\left(3^{\mathrm{e}}\right.$ édn); WHO: Geneva, Switzerland. $668 \mathrm{p}$. 
OMS. 1997. Analyse des eaux résiduaires en vue de leur recyclage en agriculture. Manuel des techniques de laboratoire en parasitologie et bactériologie, Genève, Suisse. 36 p.

Ouattara, N.K., 2012. Etude et modélisation de la contamination fécale des rivières du bassin de l'Escaut. Thèse présentée pour l'obtention du diplôme de Docteur en Sciences. Université Libre de Bruxelles. $231 \mathrm{p}$.

Palleroni, N.J., R. Kunisawa, R. Contopoulou and Doudoroff, $\mathrm{M}$. 2002. Nucleic acid homologies in the genus Pseudomonas. Int. $J$. Systematic Bacteriol., 333-339.

Rochelle-Newall, E., T.M.H. Nguyen, T.P.Q. Le, O. Sengtaheuanghoung and Ribolzi, O. 2015. A short review of fecal indicator bacteria in tropical aquatic ecosystems: knowledge gaps and future directions. Frontiers in Microbiol., 6-15.

Rodier, J. 1996. L'analyse de l'eau - eaux naturelles - eaux résiduaires - eaux de mer, 8e édition DUNOD, Paris, France. 564-571.

Rodier, J., B. Legube, N. Merlet and Brunet, R. 2009. Analyse microbiologique des eaux. In Rodier J. (ed), L'analyse de l'eau, $9^{\grave{e}}$ édition-Entione de lquesation d. Dunod, Paris (France). Pp 717-869.

Rose, J.B., S.R. Farrah, V.J. Harwood, A.D. Levine, J. Lukasik, P. Menendez and Scott, T.M. 2004. Reduction of pathogens, Indicator Bacteria and Alternative Indicators by Wastewater Treatment and Reclamation Processes. WERF final report. London, UK: IWA publishing. 1-90.

Scheren, P.A.G.M., C. Kroeze, F.J.J.G. Janssen, L. Hordijk and Ptasinski, K.J. 2004. Integrated water pollution assessment of the Ebrié lagoon, Ivory Coast. West African J. Marine Systems, 44: 1-17.

Servais, P., G. Billen, T. Garcia-Armisen, I. George, A. Goncalves and Thibert, S. 2009. Identification of human fecal pollution sources in a coastal area: A case study at Oostende (Belgium). $J$. Water Health, 4(2): 167-175.

Servais, P., T. Garcia-Armisien, G. Billen and Rousselot, O. 2006. Modélisation du niveau de contamination fécale de la Seine en région parisienne : situation présente et future. Rapport PIREN Seine.

\section{How to cite this article:}

Coulibaly-Kalpy Julien, Kouamé Y. Cyr-Kévin, Ouattara Koffi Nouho, Kouadio Kouamé, Amon Lydie Nina, Ehuié Pierre, Yéo Kadjowely, Bamba Aboubacar, Gourène Germain abd M. Dosso-Bretin Mireille. 2016. Potential Pathogenic Bacteria of Wastewater Collectors from Abidjan (Côte d'Ivoire). Int.J.Curr.Microbiol.App.Sci.5(5): 358-369. doi: http://dx.doi.org/10.20546/ijcmas.2016.505.037 